\title{
Evidence of reproductive isolation confirms that Apis andreniformis (Smith, 1858) is a separate species from sympatric Apis florea (Fabricius, 1787)
}

\author{
S Wongsiri ${ }^{1}, \mathrm{~K}$ Limbipichai ${ }^{1}$, P Tangkanasing ${ }^{1}, \mathrm{M}$ Mardan 2, \\ T Rinderer $3^{*}$, HA Sylvester ${ }^{3}$, G Koeniger ${ }^{4}$, G Otis ${ }^{2}$
}

\author{
1 Bee Biology Research Unit, Faculty of Science, \\ Chulalongkorn University, Bangkok 10330, Thailand; \\ 2 Department of Plant Protection, Universiti Pertanian Malaysia, \\ 43400 Serdang, Selangor, Malaysia; \\ 3 Honey-Bee Breeding, Genetics \& Physiology Research \\ 1157 Ben Hur Road, Baton Rouge, Louisiana 70820, USA; \\ 4 Institut für Bienenkunde $D 6370$ Oberursel 1, FRG
}

(Received 7 September 1989; accepted 29 September 1989)

Summary - The species Apis andreniformis (Smith, 1858), the small dwarf honey bee of Southeast Asia, is recognized as a valid biological species. This recognition is based on distinctive endophallus characteristics in comparison with sympatric Apis florea (Fabricius, 1787). Additionally, scanning electron microscope images of drone basitarsi are presented, as are preliminary comparisons of wing venation.

Apis florea / Apis andreniformis / taxonomy / reproductive isolation

\section{INTRODUCTION}

In 1984, our group collected dwarf honey bees in Thailand in the province of Chantaburi near the border with Kampuchea. Laboratory examinations of worker bees from these collections revealed that some bees had the species specific characteristics of Apis andreniformis (Smith, 1858) and that others had the species specific characteristics of Apis florea (Fabricius, 1787) that are reported for worker bees (Maa, 1953).

Wu and Kuang (1986, 1987) reported that secondary sex characteristics differed between drones of $A$ florea and $A$ andreformis. Specifically, both have a furcated basitarsus, presumably modified to grasp queens during mating (see Ruttner, 1988). The furcated basitarsus is quite different in

\footnotetext{
* Correspondence and reprints.
} 
the 2 groups. Following the report of $W_{u}$ and Kuang, we re-examined the sympatric populations in 4 Thai provinces, as well as bees from East and West Malaysia. Drones and workers were collected in 1988 from nests of both $A$ florea and $A$ andreniformis in the Thai provinces of Chantaburi (Southeastern), Uthaithanee (Western), Chiang Rai (Northern) and Chumporn (Southern). $A$ andreniformis was collected in 1989 in Malaysia.

Comparative studies of endophalli revealed evidence of reproductive isolation between the 2 groups, and hence confirmed the biological validity of naming 2 species of dwarf bees. In addition, drone hind legs were examined using electron microscopy, and worker bee wing venation was studied.

\section{Species-specific characteristics}

Comparisons of the endophalli of $A$ andreniformis and $A$ florea reveal numerous structural characteristics which assure complete reproductive isolation between these species (fig 1). A full or stage 9 eversion (Woyke and Ruttner, 1958; Ruttner et al, 1973) of an $A$ andreniformis endophallus has a pair of bursal cornua that fold forward once near their end; a pair of upper cornua at the sides of the vestibulum, each of which has small protrusions; a hairy field on the ventral surface that has 4 separate hairy patches distal to the primary hairy area near the vestibulum; an indented triangular hairy patch on the dorsal surface proximal to a fimbriate lobe; a fimbriate lobe having 6 small protrusions; and a comparatively thick and straight terminal portion extending distal to the fimbriate lobe.
In contrast, a full stage 9 eversion of an A florea endophallus has a pair of bursal cornua that coil or generally fold twice, a pair of upper cornua at the sides of the vestibulum, each of which is composed of 3 joined protrusions; a continuous, nonindented hairy field on the ventral surface extending from the vestibulum; a small protrusion proximal to a small dorsal hairy patch; a fimbriate lobe having 3 protrusions and a comparatively thin and strongly curved terminal portion extending distal to the fimbriate lobe.

Figure 1 illustrates these characters. The drawings are based on direct observations of several specimens as well as the accompanying photographs.

Figure 2 shows photographs of the basitarsal extensions described by $\mathrm{Wu}$ and Kuang (1986, 1987). Quite clearly, the thumb-like extension is comparatively short in $A$ andreniformis, and was absent from the only drone of $A$ andreniformis examined from Sabah, Malaysia. This extension presumably provides a "clasper organ" that fits on the queen's hind tibia during mating (Ruttner, 1975). However, whether or not this description of function is accurate awaits confirmation from observations of matings. The wing venation of Apis andreniformis workers is more similar to that of Apis dorsata and Apis koschevnikovi than it is to Apis cerana or Apis florea. The cubital index of Apis andreniformis is large $(x$ for colonies $=-6.07, N=11$ colonies, 10 worker bees each; ranges $=5.03$ to 9.21 for colony averages and 3.5 to 13.8 for individual bees) while the cubital index of $A$ florea is comparatively small ( $x$ for colonies $=2.78, N=6$ colonies, 10 worker bees each; ranges $=2.53$ to 3.14 for colony averages and 1.93 to 5.27 for individual bees). 

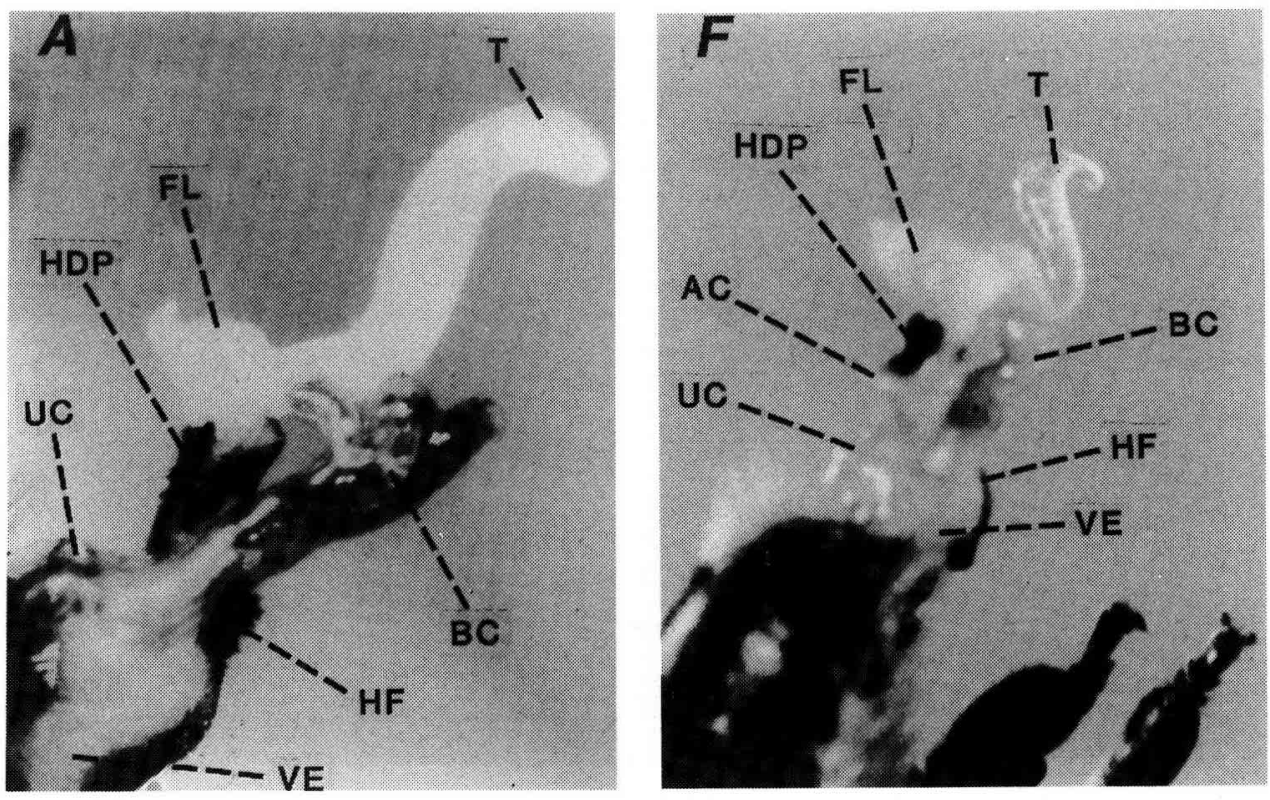

A
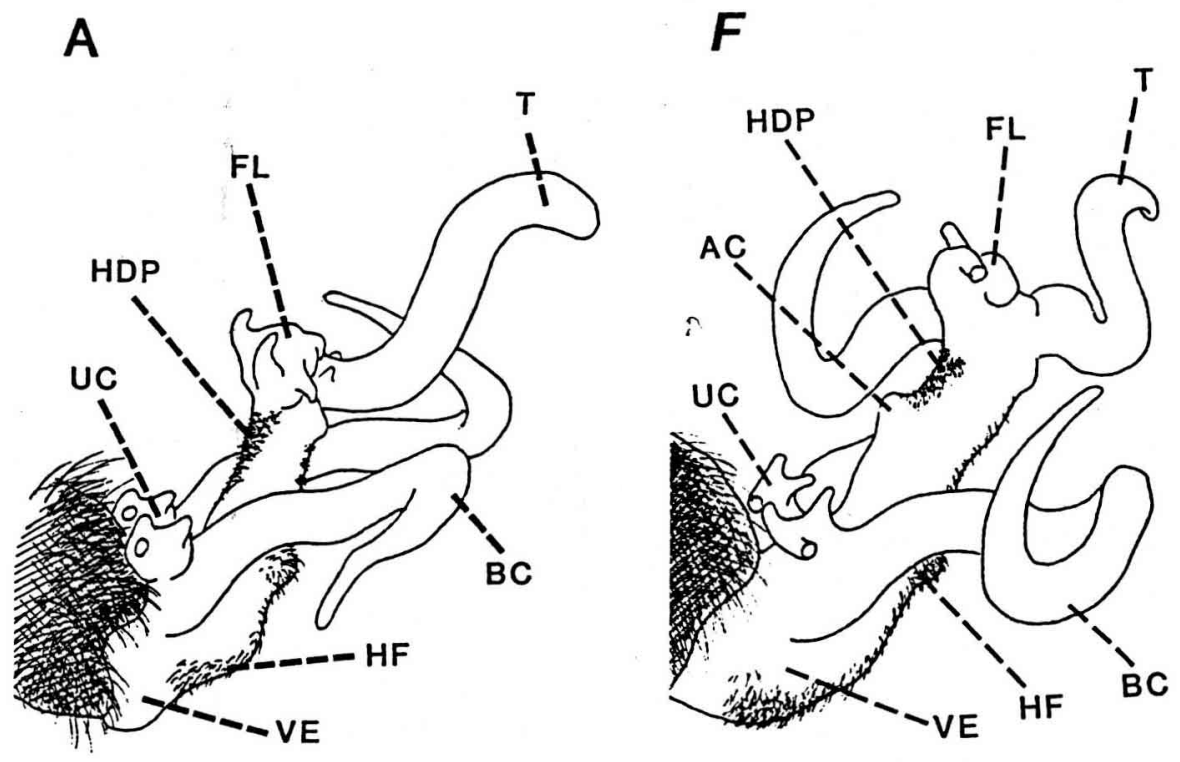

Fig 1. Photograph and drawing of the Apis andreniformis endophallus (A) and of the Apis florea endophallus $(F)$. $A C=$ additional cornua, $B C=$ bursal cornua; $F L=$ fimbriate lobe, $H D P=$ hairy dorsal plate, $\mathrm{HF}=$ hairy field, $\mathrm{T}=$ terminal portion of endophallus, $\mathrm{UC}=$ upper cornua, $\mathrm{VE}=$ vestibulum of endophallus. 

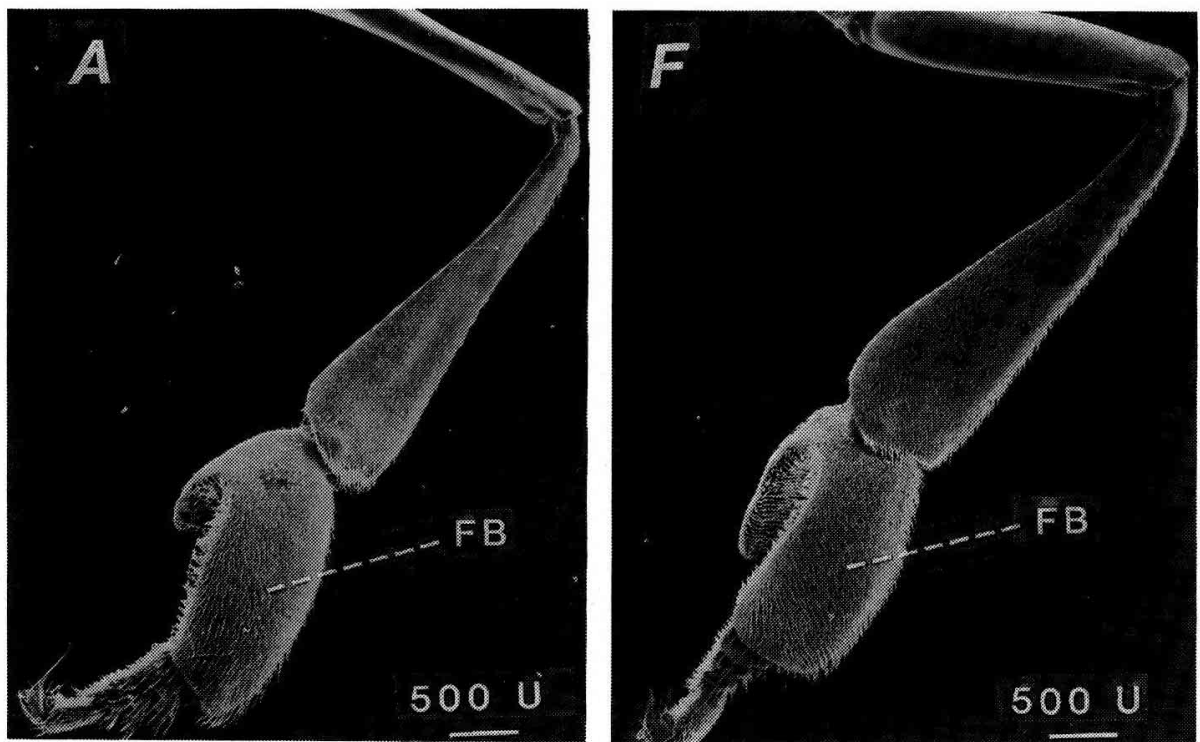

Fig 2. The hind legs of an Apis andreniformis drone (A) and an Apis florea drone (F). These electron micrographs show the short and long basitarsal extensions of males of the two species of dwarf bees.
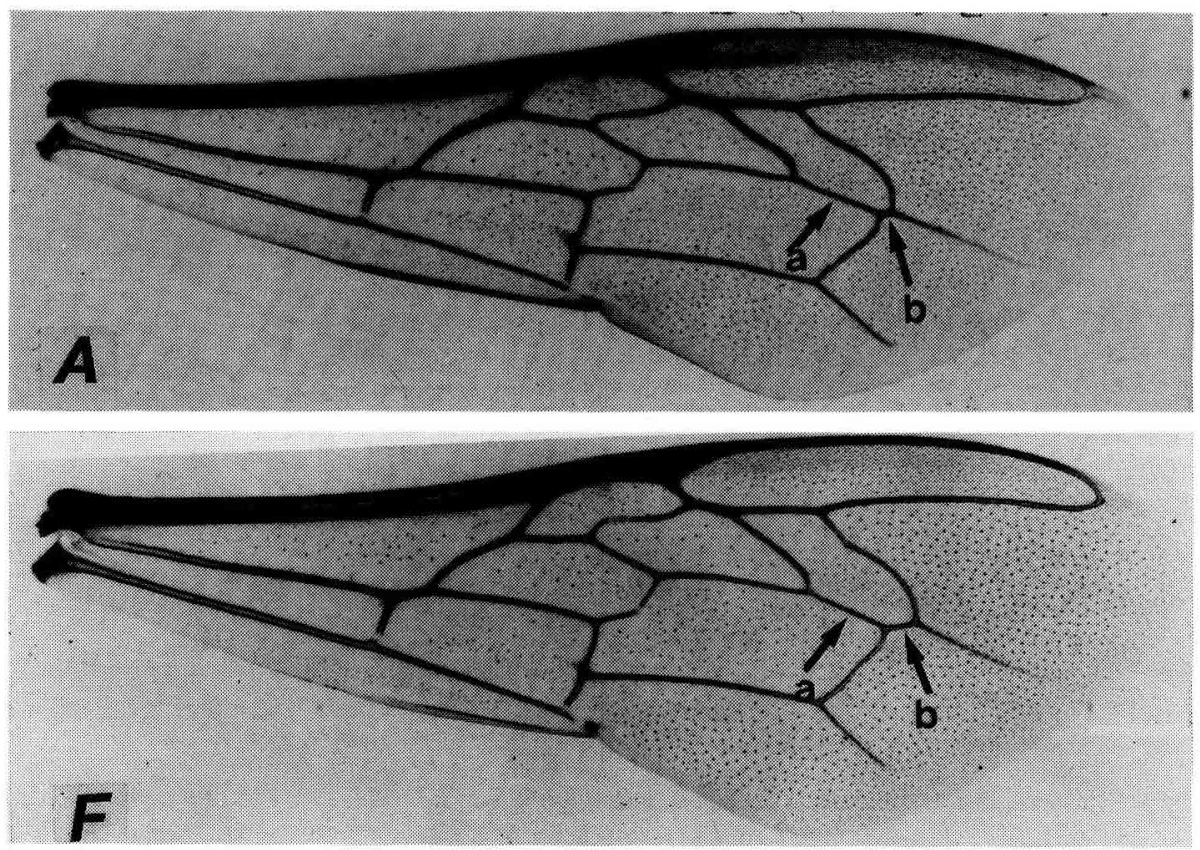

Fig 3. The fore-wings of workers of Apis andreniformis (A) and Apis florea (F) showing marked differences in cubital index, the ratio of the length of vein segments $a / b$. 


\section{CONCLUSION}

Apis andreniformis (Smith, 1858) is a valid biological species which is found in southeast Asia and is sympatric with Apis florea in much of Thailand. It is also found in the Southern China peninsula, Malaysia and Borneo but its exact distribution and sympatry with Apis florea are unknown. Equally unknown are most comparative aspects of $A$ andreniformis biology. Much that was published concerning $A$ florea may be $A$ andreniformis biology. Extensive comparative studies are required to describe and properly attribute known dwarf honey bee biology to the correct species and discover what is unique to each species.

\section{ACKNOWLEDGMENTS}

In cooperation with the Louisiana Agricultural Experiment Station. Sincere appreciation is expressed to Gerard Perrone for his work in preparing the figures. We thank $\mathrm{H} V$ Daly, $\mathrm{N}$ Koeniger, $B$ Oldroyd and $F$ Ruttner for suggestions concerning the manuscript. G W Otis was supported by a research leave grant from the University of Guelph, Guelph, Ontario. Financial support was provided by the Research Affairs Division of Chulalongkorn University, Bangkok, Thailand.

Résumé - La preuve de l'isolement sexuel confirme qu'Apis andreniformis (Smith, 1858) et Apis florea (Fabricius, 1787) sont deux espèces sympatriques séparées. Apis andreniformis (Smith, 1858) et Apis florea (Fabricius, 1787) ont été trouvées en position de sympatrie dans les régions thaillandaises suivantes : Chantaburi, Uthaithanee, Chiang Rai et Chumporn. L'examen de l'endophallus des mâles de ces abeilles naines a révélé des différences dans presque tous les détails de structure (fig 1) : dans les cornules ven- trales $(\mathrm{BC})$ et dorsales (UC), dans la surface pileuse ventrale (HF) et dorsale (HDP), dans le lobe feuilleté (FL) et dans la longueur et la forme de la partie terminale qui s'étend après le lobe feuilleté (T). Ces différences sont la preuve de l'isolement reproductif des deux espèces sympatriques et donc, la preuve qu'il s'agit bien dans le cas présent de véritables espèces. Les endophallus d'A andreniformis de Thaillande et de Malaysie sont semblables.

Sont jointes en outre des photos au microscope électronique de l'extension basitarsale caractéristique des pattes antérieures des mâles des deux espèces (fig 2). Les photographies de l'aile antérieure des 2 espèces montrent clairement l'index cubital élevé, caractéristique d' $A$ andreniformis $(x=-6,07)$ et celui petit, caractéristique d'A florea ( $x=-2,78$ ) (fig 3 ).

$L a$ répartition précise d'A andreniformis aussi bien que sa biologie sont encore inconnues. Des études comparatives sont nécessaires, car dans le passé certains caractères $\mathrm{d}^{\prime} A$ andreniformis ont certainement été attribués à tort à $A$ florea.

Apis florea / Apis andreniformis / systématique / isolement sexuel

Zusammenfassung - Der Beweis tür die reproduktive Isolierung bestätigt, dass Apis andreniformis (Smith, 1858) eine von der sympatrischen Apis florea (Fabricius, 1787) getrennte Art ist. Apis andreniformis (Smith, 1858) und Apis florea (Fabricius, 1787) wurden in folgenden Provinzen von Thailand sympatrisch nachgewiesen : Chantaburi, Uthaithanee, Chiang Rai und Chumporn. Untersuchungen des Endophallus der Drohnen beider Zwergbienen ergaben bei folgenden strukturellen Einzelheiten Unterschiede (Abb 1) : bei den ventralen (BC) und dorsalen (UC) Hörnchen 
(Cornua), beim ventralen Haarfeld (HF), beim dorsalen Haarfeld (HDP), beim Federanhang ( $F L$ ) und in der Länge und Form des Endteils nach dem Federanhang (T). Diese Unterschiede sind Beweise für eine reproduktive Isolation zweier sympatrischer Formen, also Beweise, dass es sich hierbei um echte Arten handelt. Die Endophalli von $A$ andreniformis von Thailand und Malaysia sind ähnlich.

Zusätzlich wurden elektronenmikroskopische Fotos über den basitarsalen Fortsatz (Klammerorgan) des Hinterbeins der Drohnen von beiden Arten beigefügt (Abb 2). Fotografien der Vorderflügel beider Arten zeigen deutlich den charakteristisch grossen Kubital-Index von $\boldsymbol{A}$ andreniformis $(x=6,07)$ und den charakteristisch kleinen Kubital-Index von $A$ florea $(x=-2,78)$ (Abb 3).

Sowohl die genaue Verbreitung von $A$ andreniformis als auch ihre Biologie sind noch unbekannt. Vergleichende Untersuchungen sind nötig, da in der Vergangenheit sicher einige Eigenschaften $\operatorname{der} \boldsymbol{A}$. andreniformis fälschlich $A$. florea zugeordnet wurden.

\section{Apis florea / Apis adreniformis / Taxonomie / reproduktive Isolierung}

\section{REFERENCES}

Fabricius JC (1787) Mantissa Insectorum Vol I Proft. Hafniae

Maa T (1953) An inquiry into the systematics of the tribus Apidini or honey bees Hym. Treubia 21, 525-640

Ruttner F (1975) Ein metatarsaler Haftapparat bei den Drohnen der Gattung Apis (Hymenoptera: Apidae). Entomol Germanica 2, 2229

Ruttner F (1988) Biogeography and taxonomy of honey bees. Springer Verlag, Berlin NY

Ruttner F, Woyke J, Koeniger N (1973) Reproduction in Apis cerana 2. Reproductive organs and natural insemination. $J$ Apic Res $12,21-34$

Smith F (1858) Catalogue of the Hymenopterous insects collected at Sarawak, Borneo; Mount Ophir, Malakka; and at Singapore, Wallace AR. J Proc Linn Soc London Zool 2, 42-130

Woyke J, Ruttner H (1958) An anatomical study on the mating process in the honeybee. Bee World 39, 3-18

Wu Y, Kuang B (1986) A study of the genus Micrapis (Apidae). Zoological Research 7, 99102, In Chinese

Wu Y, Kuang B (1986) Two species of small honeybee - A study of the genus Micrapis. Bee World 68, 153-155. A translation of Zoological Research 7, 99-102 